\title{
Local knowledge system in music education culture at indigenous community Kampung Naga Tasikmalaya Regency
}

\section{$\bowtie$ Sandie Gunara}

\author{
Faculty of Art Education and Design, Universitas Pendidikan Indonesia, Indonesia
}

Received: February 20, 2017. Revised: March 19, 2017. Accepted: April 2, 2017

\begin{abstract}
This study aims to investigate the teaching culture in the indigenous community. This study explores the local knowledge system in the practice of music teaching in an indigenous community of Kampung Naga, Tasikmalaya regency. This is an ethnographic research to give a detailed analysis on each case and to understand the phenomena from the point of view of the doers. This study documents the local knowledge system in music teaching culture in Kampung Naga, including nu dirampa (tried, explored), nu dirasa (perceived, contemplated), and nu nyata (used, applied). Hopefully, these findings can be the foundation of education, conservation, and innovation, and also as skills to improve the society's welfare, not only Kampung Naga society, but also other societies, especially in the context of education at school.
\end{abstract}

Keywords: local knowledge system; education culture; music education; indigenous community of Kampung Naga

How to Cite: Gunara, S. (2017). Local knowledge system in music education culture at indigenous community Kampung Naga Tasikmalaya Regency. Harmonia: Journal of Arts Research And Education, 17(1), 48-57. doi:http:/ / dx.doi.org/10.15294/ harmonia.v17i1.8773

\section{Introduction}

Education is human's effort to develop humanity values. Through education, human tries to develop civilization needed in life. Therefore, education has become everyone's basic need. The need of education is believed to be a source of human's success and welfare. Education empowers human's potential to inherit, develop, and build the future culture and civilization. On one side, education conserves positive cultural values, and on the other side, it creates changes towards more innovative life.

An educational process which brings people to success and welfare, does not develop at school only but also in the society, especially indigenous community which has become its local knowledge system.

Based on its local knowledge, the indigenous people have their own way to see and connect to the world, universe, and other people (Ascher, 2002; Barnhardt and Kawagley, 2005). Their traditional education, developed from the process of observing and adapting the nature around them naturally (Barnhardt and Kawagley, 2005). Their local knowledge plays an important role to decide how they should connect with the universe and the outside world (Gunara dan Setiawan, 2016). Battiste (2002) states that their local knowledge derives from the process of creation and has a sacred purpose. All are attached and related to nature, human being, and hu-

\footnotetext{
${ }^{\boxplus}$ Corresponding author: Jalan Setiabudi No.229, Isola, Sukasari, Kota Bandung, Jawa Barat 40154

E-mail: sandiegunara@upi.edu
} 
man existence itself. Education is seen as an enduring responsibility. As through education, people get knowledge which teaches them how to be responsible for their life and society.

Grenier (1998) reveals that local knowledge is related to indigenous, traditional, unique knowledge living in and developed by certain society condition. He thinks that local knowledge is dynamic. New knowledge develops continuously. The existed local knowledge will adapt new knowledge to be developed in the local situation.

In the indigenous community, especially in Africa, Latin, Asia, and Oceania, local knowledge is a rationalization of everyday life practices that are useful to groups living in a particular region. For such community groups, local knowledge reflects a way of life with nature, cultural beliefs and origins for the well-being of their lives (Semali and Kincheloe, 1999). Thus, local knowledge of indigenous people is derived from the learning process, social life, history and identity. This reflects their unique way of understanding life and how that knowledge can solve problems in a specific context.

Studies related to local knowledge systems in indigenous people have been widely done (Alwasilah, et al., 2009; Abrokwaa, 1999; Semali and Kincheloe, 1999; Choudry, 2010; Grenier, 1998; Nurjanah, et al., 2013; J Abah and Denuga, 2015; Kaino, 2013; Thaman, 2009). The results of the study written in this article are a review of indigenous knowledge of indigenous people, as has been revealed by the researchers. The local knowledge-the local knowledge they studied, has been fundamentally awakened for centuries, in the form of messages and customs believed by the people and passed on from generation to generation. The local knowledge is expressed in music, dance, culture, beliefs, education, rituals, customary law, agricultural practices, living tools, and so on. Of course, this form of knowledge is not structured systematically in the form of curriculum as it is implemented in formal education.
Local knowledge is shaped by informal education through natural and traditional processes. And the purpose of this article is to outline the local knowledge system studied in the context of music education practices that evolve over time and is still actively implemented. Local knowledge system in the practice of music education took place in indigenous community Kampung Naga Tasikmalaya regency, West Java Province.

\section{Method}

The method used in this research is ethnography. This method comes from the field of anthropology. "Ethno" means person or society, while "graphy" refers to the description of something. Thus, ethnography is a description of the culture and way of life understanding that stems from the views of its people (McIntyre, 2008).

Ethnographic methods are chosen as the author tries to explore specific topics to help understand the immediate issues of his support community or persons associated with this issue, keeping in mind how informants describe and formulate answers. Thus, the informant's perspective on questions related to local knowledge systems in the practice of music education in Kampung Naga indigenous communities is accurate.

As an ethnographer, the author has observed what happened, interviewed and listened to what the informants have said, and asked for all matters related to the research problem. The author has collected a lot of data which provide an understanding of the issues of this research.

In collecting the data, the authors start by getting used to writing or recording events and all the activities of indigenous Kampung Naga, both in memo book and also handycam recordings. During this study, the author has field notes. These records make it easy for writers to keep up to date during this research process. The author as the main instrument in this study, has a vital role in producing, measuring, and recording information or data. More 
information is recorded, allowing authors to obtain clear data, but the author's sharp ability in writing field notes is required to make the process effective and productive.

All the information in Kampung Naga, in a short period of time, quickly passed and then lost. Therefore, the author takes notes and records what happened as soon as possible using camera and audio recorder to save all data.

\section{Results and Discussion}

\section{Kampung Naga Existence Nowadays}

Kampung Naga is a village inhabited by a group of people who are still upholding the customs of their ancestral heritage. This is clearly visible when compared with other Tasikmalaya people living outside Kampung Naga. The Kampung Naga community lives in order that is conditioned in an atmosphere of modesty and environment of indigenous wisdom (Nurjanah, 2013, Gunara and Setiawan, 2016).

Administratively, Kampung Naga is located in Neglasari Village, Salawu Subdistrict, Tasikmalaya Regency, West Java Province. It is located around 27 kilometers from the city of Tasikmalaya to Garut direction and from the town of Garut, it is at 30.5 kilometers Tasikmalaya direction. This area is located at an altitude of 448 meters above sea level (Nurjanah, 2013).

There are 315 people living in Kampung Naga, 157 men and 158 women of 108 households. The number of residential areas of Kampung Naga of the number of the new buildings will not be expanded. This is not taboo, but is strictly constrained by the limited land. If it is imposed to enlarge the housing area, the farming area which is narrow already will be seized. Therefore, if they want to build a house, they must voluntarily look for a place outside Kampung Naga (Nurjanah, 2013; Gunara and Setiawan, 2016).

This village is in a fertile valley, with borders, to the west of Kampung Naga is bordered by a sacred forest because within the forest there is the tomb of the an- cestors of the highly respected Kampung Naga community, known as Leuweung Hadepan (Hutan Depan). To the east there are rice fields, to the south, it is also limited by the rice fields of the population, and to the north, it is limited by the Ciwulan River whose source of water comes from Mount Cikuray in Garut area. In this river stream, there is also a very sacred Dragon Forest called Leuweung Larangan (Hutan Larangan). The village area is limited, so it cannot be expanded to residential areas (Nurjanah, 2013, Gunara and Setiawan, 2016).

The settlement of Kampung Naga is concentric or grouped with empty land in the middle. Kampung Naga is located on a 1.5-hectare land area which has different heights. This situation resulted in established houses located on different sections of the soil, arranged on a different level, from the high land to the lowest land (Nurjanah et al, 2013).

The houses are the house on stilts with space beneath the house functions as chicken or duck coop, or as an agricultural tool and firewood storage. Kampung Naga residents call the house as they call themselves as the house has a head, body, and legs. The houses in Kampung Naga basically have the same basic pattern, arranged lined extending from west to east, rectangular in length and face to face. The function of the house that facing each other is to make the residents pay attention and communicate with each other s, in accordance with their lifestyle that is to hold togetherness and have a family life (Nurjanah et al, 2013).

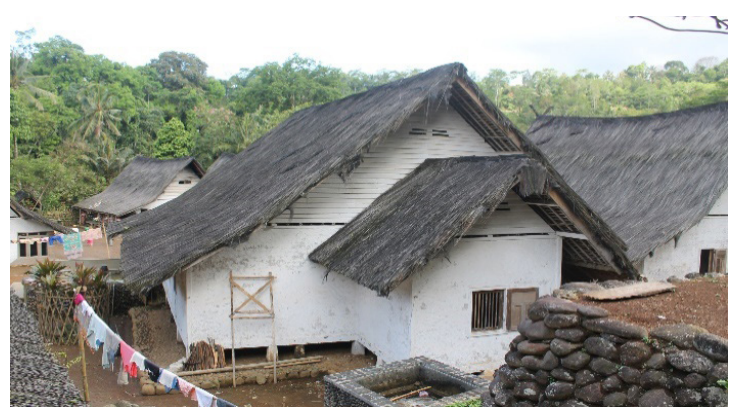

Figure 1. The housing pattern of Kampung Naga (Photo: Nurjanah, dkk) 
The settlements and valleys area including the cultivated fields, bordered on the north by Nangtang Village, in the south by Kampung Legok which is still part of Neglasari Village, in the west by Tonjong Village Sukahurip Village, East bordering Babakan Village is still Neglasari Village (Nurjanah, 2013).

According to Nurjanah et al (2013), Kampung Naga comes from the Sundanese word "nagawir" or cliff because the village is surrounded by cliffs. The word "Naga" is taken so that people are more familiar with the name of the village. Kampung Naga has been established since 500 years ago.

In addition, according to the elders of Kampung Naga, until now no one knows the origin of Kampung Naga (Kang Entang, interview July 23, 2016). They, as citizens of the original descendants, are not sure how they can exist and live there. This is because all data including ancient texts have been burned by DI-TII rebels in 1956.

The incident not only caused a long trauma, considering its loss not only in material form, but what is even sadder is that the event has caused Bumi Ageung (sacred house) burned down. For residents of Kampung Naga, Bumi Ageung is the only building that is always maintained and cared for well. The building is used to store heirlooms that have a relationship with their ancestors. In addition to the keris, spear, and other equipment, the place is stored manuscript leaf and copper plates. Heirlooms made of iron were found again. But the manuscript has turned into ash and the copper charter is hard to be recognized anymore (Nurjanah, 2013).

Currently, Kampung Naga is still well maintained. But because of the development of the times and necessities of life, in general the people of Kampung Naga are divided into two groups, namely: 1) A community group of Kampung Naga residing in the Kampung Naga residence itself; 2) A community group of Kampung Naga located outside the settlement called Sanaga (Kang Entang, interview 23 July 2016; Nurjanah et al., 2013).
Based on Nurjanah et al's study (2013) and Kang Entang's statement (an elder at Kampung Naga) (interviewed, on July 23,2016), there are several factors causing the migration of residents from Kampung Naga out of the village. First, the result of marriage with members of Kampung Naga community living outside the village, or with other members of the community outside their community. Secondly, for economic reasons, so with a more practical choice, they choose to live outside Kampung Naga to open their business. Third, due to limited land available in Kampung Naga, the newly married couple prefer to settle or build a house outside Kampung Naga with the consideration that the land in Kampung Naga is not possible to build a new house. Therefore, if the number of families increases and no longer possible to live in one house, then the family must build a house and live outside Kampung Naga. However, at certain times, they gather in Kampung Naga.

Basically, those who live outside Kampung Naga are still bound by the village custom and are still recognized as part of their community. So in every ceremony of the traditional ceremonies, they come to Kampung Naga to make pilgrimages to the sacred tombs that are considered as the graves of their ancestors. However, for those who live outside Kampung Naga, they are not bound by the terms and conditions to make the house on stitlts and other rules (Nurjanah et al, 2013).

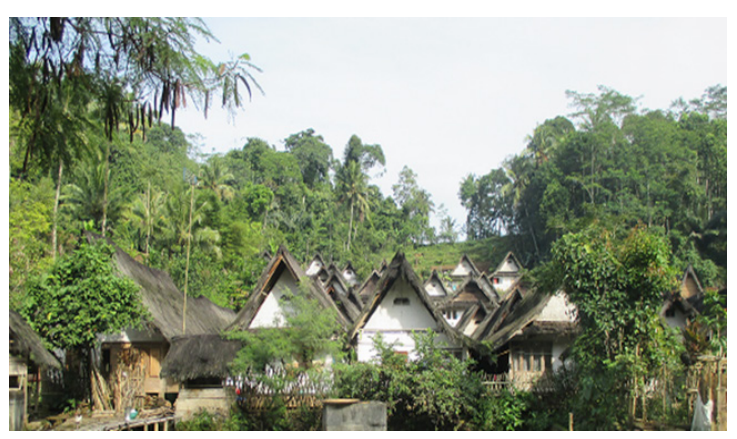

Figure 2. The Atmosphere of Kampung Naga (Photo: Sandie Gunara). 
Life Pattern of Indigenous People of Kampung Naga

The indigenous people of Kampung Naga are part of Sundanese society who are productive cultivators. They produce their own food by farming in the hills. As productive people, they are not always dependent on nature. This indicates that they never conflict with nature, it raises one thought of appreciation of nature. The appreciation and harmony of nature are formed from the three patterns that they have been practicing as cultivators.

The three patterns in pre-modern Indonesian culture flourish in primordial society living by farming. The cultivators are those living from rice farming, usually in hilly areas (Sumardjo, 2011). According to Sumardjo, the mindset of the cultivators is different from the gathering community. Nevertheless, there are still mixing characteristics. The people are no longer fully dependent on nature because they can produce their own food by farming. The cultivators do not take full advantage of farming. They still need forests, especially when old fields are unproductive due to reduced fertility value.

The pattern of three raises a harmony. Harmony does not eliminate the first two entities, but "marry" them. In marriage, men remain men, women remain women, and both merge into a single entity that gives birth to a family entity, the child. A harmony is a paradoxical event, nothing is defeated, and nothing is won. Both are winners, even give birth to new life (Sumardjo, 2011).

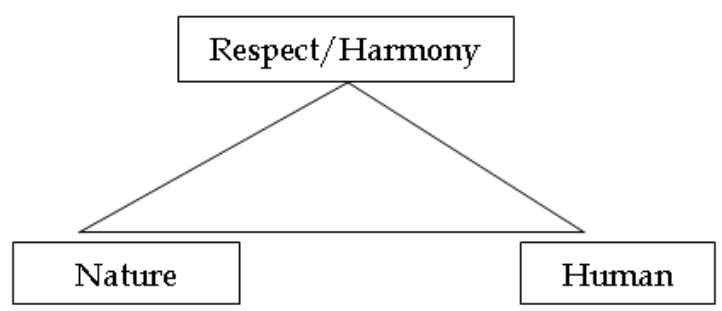

Figure 3. The Pattern of Three in the life of the indigenous people of Kampung Naga

Figure 3 above shows a Sundanese mindset that is called tritangtu principle or a three-unit (Sumardjo, 2011). The principle of tritangtu in Sundanese society is based on repeated expression which is the unity of three words (Sumardjo, 2011). Determination, speech, lampah - silih asah, silih asih, silih asuh. When compiled, the words that exist in the Sundanese people, will be a very long list. The expressions of the unity of the three words are symptoms that show that there is a hidden concept or a cultural rationality which is the basis of the circulation of those phrases. If that is true, then there is a system of local knowledge that is rationalized for a very long time, so it becomes the philosophy of life of Sundanese society itself.

The principle of unity-three or tritangtu, is the basic principle of the old Sundanese society. According to Sumardjo (2011), tritangtu is a cultivator's world view, as well as indigenous Kampung Naga. The farming community initially believed that all aspects of life were dualistic, but all the dualistic things are binary pairs that often cause conflict conditions. This condition should not be allowed because it will cause extermination. Therefore, harmony between the dualistic pair is required. The harmony is an integration between the dualistic, so as to bring up the "third". Thus, dualistic thinking is transformed into a three-or three-point unity pattern, also called tritangtu.

Thus, the attitude of appreciation or harmony with nature is a "third" element. By appreciating this nature makes the Kampung Naga indigenous people always limit their productive activities. They cultivate on limited land, not excessive, only on the determined place. The concept of the above three patterns has become a system of local knowledge in their life. Even these three patterns occur also in the context of educational culture within the indigenous community as a whole.

\section{The Principle of Tritangtu inMusic Education Culture of the Indigenous People of Kampung Naga}

From a simple residential atmosphere and supported by the beautiful and still 
very traditional kampung environment (see Figure 1 and 2), the indigenous people in Kampung Naga live their daily lives subject to and adhere to the rules set forth in the customary form, which includes all habits, duties and rituals or pamali (taboo) that serve as guides for good and right behavior. These rules are regarded as sacred, derived or inherited from the ancestors and must be carefully guarded. They consider that, the rule is an instrument to maintain the balance of the relationship between human and nature in order to maintain their survival (Nurjanah, 2013).

From customary rules that have been used for hundreds of years, local knowledge system of indigenous people Kampung Naga were produced; one of which is in the culture of education. There is a way to educate, how to learn and how the elders re-teach it to the young generation. One of them is in the practice of music education as an attempt to inherit or to transmit music tradition.

In the practice of music education that they do so far, there are unique ways that can be studied more deeply. Inheriting the traditional music, for indigenous peoples such as Kampung Naga, is something that is important to do. It is intended that the continuity of traditional rituals or ceremonies where music becomes one of the media, can continue. The music that has been continuously regenerated is Terebang Gembrung and Terebang Sejak, their original art. Their concern for the continuity of both traditional music is very high, so it must be taught or inherited so as not to disappear (Gunara and Setiawan, 2016).

In Kampung Naga, music and life has become an integral part. The practice of their lives has been going on for hundreds of years. This means that their system of local knowledge in the practice of music education as an effort to retain and pass the arts between generations, for the continuity of the activities of ritual ceremonies, proved successful. Their local knowledge system deserves to be a source of innovation and skills that can be empowered for the welfare of society, not only for Kampung Naga people, but also for the public in general especially in the context of education in schools.

The new generation of Kampung Naga certainly does not think that they will be born into a reality of life that they live at this time. Wood framed house and coconut-fiber roof, with the walls of houses made of bamboo cubicles and live without electricity. Since being born into a part of indigenous people who adhere to tradition, it is certainly inherited by way of life as their parents did long ago. There is an educational process that has educated them to survive to this day. The educational process they undertake indirectly has become their local knowledge system. When the boys and the girls in the Kampung Naga community begin to marry, the knowledge system they inherit, is re-applied to educate their children according to what their parents taught them.

The system of local knowledge in the culture of education in the Kampung Naga, oriented in the past to establish the continuity of their existence. Through their knowledge, they are able to strategize to achieve the future they want. This system of local knowledge they apply in the practice of music education Terebang Gembrung and Terebang Sejak.

This system has become a pattern they used a long time ago. The pattern is nu dirampa (tried, explored), nu dirasa (perceived, contemplated), and nu nyata (used, applied). As Sumardjo (2011) has pointed out about the pattern of three or tritangtu discussed earlier, in the culture of music education in Kampung Naga, there are also three patterns (see figure 4).

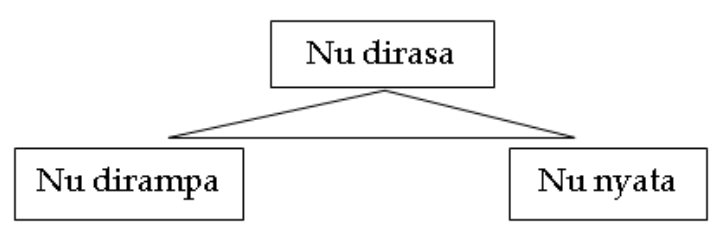

Figure 4. Pattern of three in music culture education in Kampung Naga

The basis of the cosmological beliefs of Kampung Naga in the culture of music 
education above (figure 4) becomes the basis of the way of thinking for all things, namely the pattern of three. As Sumardjo (2011) points out, the basic belief of this three-pattern is based on the antagonistic dualism belief of all things. The sky above, the Earth below. The sky is wet, the Earth is dry. The sky is female, Earth man, the sky is bright, dark Earth. Both are separate and distant. Partition is not good, because it will bring death. The separation of all things that dualistic antagonistic must end, ie by marrying both. Life is possible because of harmony. The requirement of life is the harmony of two conflicting but complementary entities.

When interpreting from field findings related to pattern three in the musical culture culture of Kampung Naga (see figure 4) with the cosmological beliefs described by Sumardjo, there is something very interesting. The concept of $n u$ dirasa (perceived, contemplated) does not eliminate the original two concepts, namely, nu dirampa (tried, explored) and nu nyata (used, applied), but merged.

The concept of nu dirasa is the middle part which contains two contradictory concepts, namely nu dirampa and nu nyata. The concept $n u$ dirasa is the relator, medium, intermediaries that bridge the two concepts that contradict earlier. The existence of the concept $n u$ dirasa does not allow any contradiction. The opposition ends in harmony because it is complementary.

Based on the cosmological description of the local knowledge system of indigenous people of Kampung Naga above, it develops a new awareness that it turns out what the elders of Kampung Naga do to their young generation actually contains a noble meaning. Thus, it is imperative to combine traditional and modern education. Because according to J. Abah and Denuga (2015), thousands of years of local knowledge systems of indigenous people all over the world live and have their own educational system, long before modern education was introduced by the colonialists.

The modern educational system cur- rently exposes learners to the contradictory demands of schooling (modern) with local education because the purpose, content, and transmission of knowledge processes contradict the origins of its local cultural education system (Thaman, 2009; J. Abah and Denuga , 2015).

In some indigenous communities throughout the world, there has been a living knowledge system that can be integrated into the school curriculum system, to improve learning outcomes. This local knowledge system can be an important tool to use in bridging the gap between what is taught in the classroom (the modern knowledge system) and what is outside the classroom (the local knowledge system) (Kaino, 2013).

To that end, the authors believe that the study of the local knowledge system of indigenous Kampung Naga in the practice of music education should be done, considering the music education practices in the classroom that developed in Indonesia today is more directed to Western models such as Kodaly, Dalcroze, Orff, Gordon and so on. Not to abandon these methods, because the authors believe that they are very good and are born from the context of the local community there. But it is the time we also reveal the teaching methods based on our local cultural concept, to bridge the gap earlier. In order to understand more deeply about the system of local knowledge in the musical education culture in Kampung Naga Tasikmalaya, the author will explain it below.

\section{$\mathrm{Nu}$ Dirampa: Tried and Explored}

$\mathrm{Nu}$ dirampa (tried, explored) refers to the process of direct learning and observation. In many activities while playing music Terebang, parents or elders never forbid their children to see the rehearsals or performances. Instead they allow the children to observe the exercise process, even the children are allowed to hold the instrument and try to hit it. Children also observe how parents or elders beat the instrument. Then, when the children try to themselves what they hear, the parents 
never admonish them that it is wrong or not. Parents allow children to play with the instrument. Even deliberately, the elder keeps his instrument in the hall, so it is not difficult for children to take and play with the instrument. The goal is to make it easier for children to practice and play it all the time. According to Abah Ojid as elder and coach, he also secretly sees the potential of children. He observes which children are potential to be taught to be a drummer in order for the art can be inherited.

The concept of $\mathrm{Nu}$ dirampa allows children to experience directly and allow them to explore. Let the children know about the instruments they hold and explore the sounds through musical instruments. So the concept of nu deprived is a teaching that fosters the desire, curiosity, intentions and conscience of children.

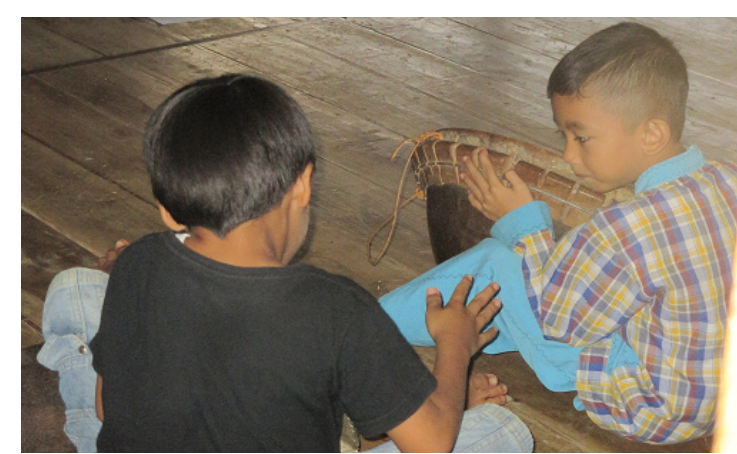

Figure 5. Two children of Kampung Naga are exploring how to beat Terebang (Photo: Sandie Gunara

$\mathrm{Nu}$ Dirasa: Perceived and Contemplated The pattern is nu dirampa (tried, explored), $n u$ dirasa (perceived, contemplated), and nu nyata (used, applied)

$\mathrm{Nu}$ dirasa (perceived, contemplated) refers to the concept of learning to beat the musical instrument terebang. The patterns of rhythm and way of tapping are taught here, starting from the simple pattern. First, Abah Ojid teaches children a rhythmic pattern that is worth one tap. Then, teach how to produce the color of sounds in music like pak, pong dan dung. The colors of the sounds are produced from dif- ferent techniques of applause. The sound of the pak is produced by the side of the musical instrument with the fingers of the hands being pushed together and hitting it by being pressed. Then the sound of the pong is produced by the side of the musical instrument with the fingers of the fingers of his hand still closed but hit not pressed but released. While the sound dung produced by the middle of the musical instrument fell by the way his fingers are not closed and hit him not pressed. All of these are taught by Abah Ojid at this stage.

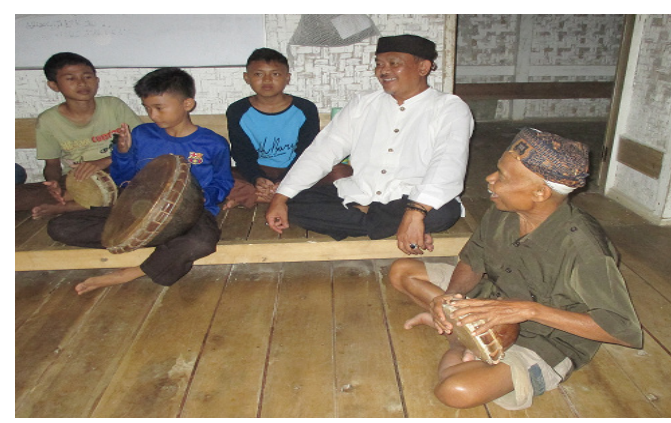

Figure 6. Kang Entang and Abah Ojid are teaching Terebang Sejak (Photo: Sandie Gunara)

In practice, the concept $n u$ dirasa is technical material. The children have started to feel the difference in the color of sound, the way of the beat and the pattern of the rhythm, strating from the simple pattern to a more complex one. From this experience, philosophically $n u$ dirasa is the center and the peak of a triangular shape (see Figure 4). Nu dirasa is the process by which children are invited to feel and reflect on their experiences. This concept is very important and fundamental in the process of education and training terebang music in Kampung Naga.

Figure 7 shows Abah Ojid, an elder as well as a coach, is modeling the patterns of applause. Then the children watch and imitate. There is no pattern written by Abah Ojid, all in his memory and experience because, in the past, he also he learned from the elders also like that (interview with Abah Ojid, July 22, 2016). 


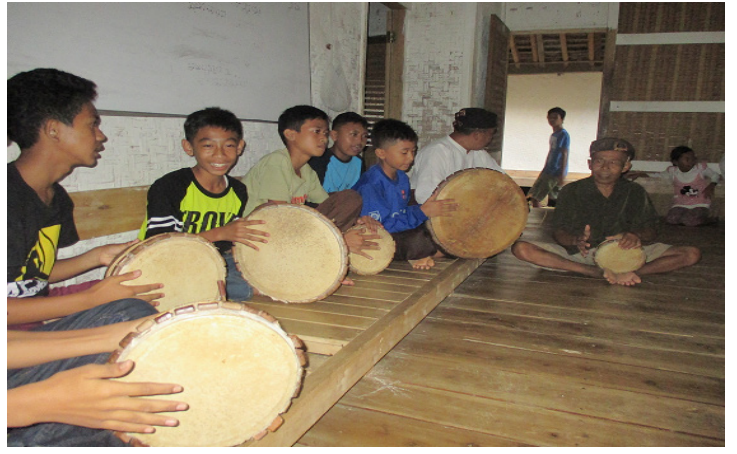

Figure 7. Kampung Naga kids are having training with Abah Ojid (Photo: Sandie Gunara)

At this stage, the musical terebang in Kampung Naga is taught informally. The children of Kampung Naga observe and then imitate what is played by the elders. The learning is done orally and the music is taught with an aural approach. The musical patterns that are taught are not written down; they are all in the memories and experiences from generation to generation. The technique teaches by way of call and response, that is, the elders mention and demonstrate patterns of applause, then the children respond by imitating what is played by the parents. The patterns taught are very simple, but the difficult thing is to connect the pattern with other members (interview with Mardiana, a child of Kampung Naga, July 23, 2016).

\section{Nu Nyata: Used and Applied}

$\mathrm{Nu}$ Nyata (used, applied) refers to the concept of learning when what has been previously learned was applied to produce beautiful music. The music does not only contain the colors of sounds and rhythm patterns, but also the lyrics that compliment the Prophet Muhammad and the life sciences. That content is then implemented in real life. Real life is not only in the context of music performances, but also in the context of everyday life. The moral messages contained in the music they ponder, feel, and carry it out in real life.

From the above discussion, it can be said that, the concept of nu dirampa, nu dirasa and nu nyata is a system of local knowledge in music education culture in Kam- pung Naga that occurred in a long time. There is a difference between the concept of learning in modern society and in the life of indigenous people. The more modern concept of learning emphasizes on results rather than meaning to life. Meanwhile, the concept of indigenous peoples is not solely on the ability of the outcome, but also the ability to live in harmony with nature and the teachings of Allah SWT.

Based on the system of local knowledge in the music education culture, learning and playing musical instruments Terebang Gembrung and Terebang Sejak, in addition to obedience to Allah SWT and praise to Prophet Muhammad SAW, indirectly also provide an identity and actively maintain the tradition that the elders have taught, so music Terebang Gembrung and Terebang Sejak representation of way of life and thinking as a Kampung Naga customary citizen, and the music of Terebang Gembrung and Terebang Sejak, that is taught to children from generation to generation, is not only aimed for preservation only, but also as a teaching for society, culture and religion.

\section{Conclusions}

The purpose of the music education process in Kampung Naga is to instill socio-cultural values to the younger generation. The educational process is not organized in a formal form, but is shaped by the natural environment. The emphasis on creating a musical situation and active participation of elders and young generations is more important than formal teaching. The practice of music teaching organized in social life like this, allows children to learn gradually and comprehensively. Not only related to the beating skills, but also related to the values of social life within the community of Kampung Naga itself.

The main teaching methods used by the elders are oral traditions, demonstrations, imitations, and memories. All of that is done in the tritangtu principle of music education culture that includes nu dirampa (tried, explored), nu dirasa (perceived, con- 
templated), and nu nyata (used, applied). This research still needs to be discussed in more detail and comprehensively about the concepts nu dirampa (tried, explored), nu dirasa (perceived, contemplated), and nu nyata (used, applied). Further studies are needed so that the idea of local knowledge in the culture of education in indigenous people can be used as a necessity and courage to counter the flow of this modern and too global-oriented education. By elevating the local knowledge system in indigenous education culture in Kampung Naga, it is expected that there is continuity with historical origins and current condition and situation, so indirectly, we will not be far from our cultural environment, both local and national.

\section{References}

Alwasilah, et al. (2009). Etnopedagogi: Landasan Praktek Pendidikan dan Pendidikan Guru. Bandung: Kiblat Buku Utama.

Ascher, Maria. (2002). Mathematics Elsewhere: An Exploration of Ideas across Culture. Princeton: Princeton University Press.

Abrokwaa, Clemente. K. (1999). Indigenous Music Education in Africa. In Ladislau M. Semali (Eds). What is Indigenous Knowledge. London: Falmer Press.

Barnhardt, Ray dan Angayuqaq Oscar Kawagley. (2005). Indigenous Knowledge System and Alaska Native Ways of Knowing. Antrophology and Education Quarterly, 36 (1), pp. 8-23.

Battiste, Marie. (2002). Indigenous Knowledge and Pedagogy in First Nation Education: A Literature Review with Recommendations. Ottawa: Indian and Northern Affairs Canada.

Choudry, Aziz. (2010). Against the Flow: Maori Knowledge and Self-Determination Struggles Confront Neoliberal Globalization in Aotearoa/New
Zealand. In Dip Kapoor and Edward Shizha (Eds), Indigenous Knowledge and Learning in Asia/Pacific And Africa. New York: Palgrave Macmillan.

Grenier, Louise. (1998). Working With Indigenous Knowledge. A Guide For Researcher. Canada: International Development Research Centre.

Gunara, Sandie dan Toni Setiawan. (2016). Eksplorasi Nilai-Nilai Kearifan Lokal Dalam Praktek Pendidikan Musik Pada Masyarakat Adat Kampung Naga Kabupaten Tasikmalaya. LPPM UPI: Laporan Penelitian.

J. Abah, P. Mashebe, and D.D. Denuga. (2015) Prospect of Integrating African Indigenous Knowledge Systems into the Teaching of Sciences in Africa. American Journal of Educational Research, 3(6), 668-673. doi: 10.12691/ education-3-6-1.

Kaino, L.M. 2013. Traditional Knowledge in Curricula Designs: Embracing Indigenous Mathematics in Classroom Instruction. Stud Tribes Tribals, 11(1), 83-88.

McIntyre, Philip. (2008). Creativity and Cultural Production: A Study of Contemporary Western Popular Music Songwriting. Creativity Research Journal, 20(1), 40-55.

Nurjanah, Nunuy. et al. (2013). Nilai-Nilai Kearifan Lokal Masyarakat Kampung Naga Tasikmalaya Sebagai Landasan Sosial Budaya Pendidikan Nasional. LPPM UPI: Laporan Penelitian.

Semali, Ladislaus M dan Joe. L Koncheloe. (1999). What is Indigenous Knowledge? New York and London; Falmer Press.

Sumardjo, Jacob. (2011). Sunda: Pola Rasionalitas Budaya. Bandung: Kelir.

Thaman, K.H. (2009). Towards Cultural Democracy in Teaching and Learning with Specific References to Pacific Island Nations (PINs). International Journal for the Scholarship of Teaching and Learning. 3(2). 